\title{
Identification of groundwater nitrate pollution sources in agricultural area using PCA and SIAR methods
}

\author{
${ }^{1}$ College of Environmental Science and Engineering, Ocean University of China, Qingdao 266100, China \\ ${ }^{2}$ Key Laboratory of Marine Environment and Ecological Education, Ocean University of China, Qingdao 266100, China \\ ${ }^{3}$ College of Engineering, Ocean University of China, Qingdao 266100, China; *Corresponding author, E-mail: zhengtianyuan@ouc.edu.cn \\ ${ }^{4}$ Center for Eco-Environmental Research, Nanjing Hydraulic Research Institute, Nanjing 210098, China
}

(Received: August 20, 2019; Revised accepted: November 23, 2019)

https://doi.org/10.18814/epiiugs/2020/020047

Groundwater nitrate sources are diverse and it is of great scientific significance to analyze the sources and respective contribution rates. However, the existed methods of source parsing have some shortcomings. Hence, this study compared principal component analysis (PCA) and Stable Isotope Analysis in R (SIAR), taking the Dagu River groundwater source in Qingdao as an example. The pollution sources analyzed by PCA are more comprehensive and more reliable than those of SIAR. For the contribution rate, the results of PCA can only provide the total contribution of the similar sources, while SIAR is able to capture the contribution rate of each pollution source. Here, we proposed a mixed method taking the advantage of the PCA and SIAR. The new approach can better determine the pollution sources and is capable of solving the contribution rate of each pollution source. Utilizing the combined method, the main sources of nitrate pollution in the Dagu River are found to be manure, $\mathrm{NO}_{3}^{-}$fertilizer, sewage, soil $\mathrm{N}$ and $\mathrm{NH}_{4}^{+}$fertilizer, with average contribution rates 27.7, 27.3, 21.8, 13.0 and 10.2\%, respectively. Through this case study, we are confirmed that this mixed method is preferred clearing pollution source and contribution rate.

\section{Introduction}

Groundwater is an essential and irreplaceable resource for economic and social development which is the major drinking water for more than 1.5 billion people worldwide (Lee et al., 2017; Wang et al., 2018). However, nitrate $\left(\mathrm{NO}_{3}^{-}\right)$pollution in groundwater has become one of the most severe environmental issues of common concern to the international community (Rebolledo et al., 2016; Ghaeminia and Mokhtarani, 2018; Raza and Lee, 2019). The excessive intake of $\mathrm{NO}_{3}^{-}$in the human body will be restored to toxic $\mathrm{NO}_{3}^{-}$and further converted into nitrosamines, which can easily lead to digestive dis- eases (Widory et al., 2004; Ma et al., 2016). Therefore, the World Health Organization (WHO) and some major countries have established corresponding drinking water standards stipulating that the maximum concentration of $\mathrm{NO}_{3}^{-}$(in N) is 10-11.3 mg/L (Baily, 2011). Meanwhile, China's drinking water standards state that the maximum allowable concentration of $\mathrm{NO}_{3}^{-}$(in N) is $10 \mathrm{mg} / \mathrm{L}$. The rural small centralized and distributed water supply regulations are $20 \mathrm{mg} / \mathrm{L}$. The highest concentration of $\mathrm{NO}_{3}{ }^{-}$in groundwater in the Shandong Peninsula from 2005 to 2012 reached $184.6 \mathrm{mg} / \mathrm{L}$, and the rate of exceeding the standard was up to $48.3 \%$ (Zhao et al., 2007). Therefore, the study of $\mathrm{NO}_{3}^{-}$pollution in groundwater has aroused widespread concern in the academic community and the analysis of pollution sources has become one of the current research hotspots.

Potential sources of $\mathrm{NO}_{3}^{-}$contamination in groundwater include chemical fertilizers used in agricultural activities, manure, industrial and domestic sewage, atmospheric nitrogen deposition, nitrogen in the soil (Soil N) (Xue et al., 2009; Kaushal et al., 2011; Jin et al., 2012). The methods for recognizing and inferring the source of $\mathrm{NO}_{3}^{-}$contamination in groundwater mainly include water quality analytical methods and stable nitrogen and oxygen isotope methods (Zhao et al., 2010). The water quality analysis method is to draw the analysis results into a six-component map and Piper map, which qualitatively analyze the sources of $\mathrm{NO}_{3}^{-}$in the groundwater (Zhao et al., 2010). In addition, some scholars input the analytical data of groundwater quality into the models of chemical mass balance (CMB), positive matrix factorization (PMF) and principal component analysis (PCA) to quantitatively address the sources of $\mathrm{NO}_{3}^{-}$pollution in groundwater (Matiatos et al., 2014; Xue et al., 2015). In recent years, PCA has widely applied to the sources analysis field (Kim et al., 2015; Matiatos, 2016) which extracts the principal components (PCs) and calculates the contribution rate through "dimension reduction" and "multiple linear regression analysis". It determines the sources of the PCs according to hydrogeological conditions. However, using this method, it is difficult to distinguish the contribution rates of each pollution source with similar pollution information (for example, sewage and manure are often treated as a single source) (Pastén-Zapata et al., 2014).

Recently, some scholars have inferred $\mathrm{NO}_{3}{ }^{-}$sources based on the 
unique nitrogen and oxygen isotope values of various $\mathrm{NO}_{3}^{-}$sources (Chang et al., 2002; Burns et al., 2009; Kaown et al., 2009; Xue et al., 2009), and combined with the Stable Isotope Analysis In R (SIAR) model to calculate contribution rate of each pollution source. The nitrogen and oxygen isotope values of different $\mathrm{NO}_{3}{ }^{-}$sources can provide a basis for predicting the sources of pollution. Xue et al. (2009) collected the ranges of nitrogen and oxygen isotopes of potential sources of $\mathrm{NO}_{3}^{-}$contamination. For example, for $\mathrm{NO}_{3}^{-}$precipitation, $\delta^{15} \mathrm{~N}_{-} \mathrm{NO}_{3}^{-}$and $\delta^{18} \mathrm{O}_{-} \mathrm{NO}_{3}^{-}$range from -13 to $13 \%$ and $25-75 \%$, respectively. The $\delta^{15} \mathrm{~N}_{-} \mathrm{NO}_{3}^{-}$and $\delta^{18} \mathrm{O}-\mathrm{NO}_{3}^{-}$of manure have characterized by ranges $5-25 \%,-10$ to $10 \%$, respectively. Soil has $\delta^{15} \mathrm{~N}^{-\mathrm{NO}_{3}}{ }^{-}$and $\delta^{18}{\mathrm{O}-\mathrm{NO}_{3}^{-}}^{-}$values in the range of $0 \%$ to $8 \%,-10 \%$ o to $10 \%$, respectively. For example, in 2016, the main sources of $\mathrm{NO}_{3}^{-}$pollution in the highly urbanized Beiyun River Basin in China were manure and sewage with the total contribution rates of 77.59 and $89.57 \%$ in the rainy and dry seasons, respectively (Liu et al., 2018). The main sources of $\mathrm{NO}_{3}{ }^{-}$pollution in Xijiang River for the rainy season are organic nitrogen and chemical fertilizer, with a contribution rate of $72-73 \%$. While, the main sources of $\mathrm{NO}_{3}^{-}$pollution for the dry season are manure and fertilizer, with $58 \%$ contribution rate (Li et al., 2019). However, the dual isotope method does not always accurately track the sources of pollution. The overlap and changes in isotopic values as a result of biogeochemical process can cause inaccurate identification of pollution sources (Wang et al., 2017).

In this study, taking the groundwater source of Dagu River in Qingdao as an example, we compared the analysis results of PCA and SIAR to clear the pros and cons of the both approaches, and then proposed a novel method that combines the advantages of the two approaches. Finally, using the combined method, we can accurately analyze the sources and contribution rate of $\mathrm{NO}_{3}^{-}$pollution in the groundwater source of Dagu River. The main research purposes of this study are (1) to emphasize that the multivariate statistical method is slightly superior to the dual isotope method in determining the sources of $\mathrm{NO}_{3}^{-}$contamination and the isotope method is superior to multivariate statistical method in calculating the contribution rate of pollution sources; (2) to prove that this mixed method can preferred clear pollution sources and contribution rate; (3) to provide theoretical support for reducing $\mathrm{NO}_{3}^{-}$pollution and rationally distributing the load of each pollution source.

\section{Materials and Methods}

\section{Study Area}

The Dagu River is the largest river in the Shandong Peninsula, China. The length of the main stream is $179.9 \mathrm{~km}$ with the total drainage area of $6131.3 \mathrm{~km}^{2}$. The Dagu River groundwater source is located in the middle and lower reaches belonging to Pingdu, Jimo, Laixi, Jiaozhou and other urban areas in the administrative division. The groundwater source area is around $421 \mathrm{~km}^{2}$ and the geographical coordinates are $120^{\circ} 04^{\prime} 48^{\prime \prime}-120^{\circ} 21^{\prime} 00^{\prime \prime} \mathrm{E}$ and $36^{\circ} 18^{\prime} 00^{\prime \prime}-36^{\circ} 45^{\prime} 45^{\prime \prime} \mathrm{N}$ in Fig. 1a (Liu et al., 2017).

There is a temperate monsoon continental climate with typical marine climate characteristics within this area. It is hot and rainy in the summer, cold and dry in the winter, and pleasant in the spring and autumn (Liu et al., 2017). The monthly precipitation distribution in this area is rather uneven and the precipitation from July to September accounts for approximately $70 \%$ of the annual precipitation.

The groundwater of the Dagu River mainly exists in the sand and gravel layers in the lower part of the Quaternary alluvial deposit, the water-bearing layer is a thin phreatic aquifer covered with a weakly permeable clay (e.g. sandy clay). Groundwater in the region is recharged from atmospheric precipitation, river infiltration and irrigation, and is drained for the industrial and agricultural usage (Fang et al., 2018). The groundwater level is $0.5-4 \mathrm{~m}$ to the surface. The variation of the groundwater level within a single year is generally $2-3 \mathrm{~m}$ (Liu et al., 2017). The direction of groundwater flow in the study area is consistent to the direction of the main stream of the Dagu River, from north to south (Fang et al., 2018).

The land use in this area can be classified as cultivated land, forestland and grassland, of which grain planting area accounts for $65-80 \%$ and vegetable planting area accounts for $10-20 \%$. The amount of used pesticides is generally $4.5-13.5 \mathrm{~kg} / \mathrm{hm}^{2}$ and about $500-600 \mathrm{~kg} /$ $\mathrm{hm}^{2}$ for the chemical fertilizer with the nitrogen fertilizer of approximate $50 \%$.

\section{Sampling}

In April 2015, 29 sampling sites were selected in the Dagu River water source (Fig. 1b), and the concentrations of $\mathrm{Ca}^{2+}, \mathrm{Mg}^{2+}, \mathrm{Na}^{+}, \mathrm{Cl}^{-}$ and $\mathrm{SO}_{4}{ }^{2-}$ in groundwater were determined by an ion chromatograph. The concentrations of $\mathrm{NH}_{4}{ }^{+} \mathrm{N}, \mathrm{NO}_{2}^{-}-\mathrm{N}$ and $\mathrm{NO}_{3}{ }^{-}-\mathrm{N}$ were measured by the Nessler reagent, $\mathrm{N}-(1$ naphthalene)-ethylenediamine hydrochloride and ultraviolet spectrophotometry, respectively. The concentration of $\mathrm{HCO}_{3}^{-}$was identified by titration (Table 1 ).

$\delta^{15} \mathrm{~N}_{-} \mathrm{NO}_{3}^{-}$and $\delta^{18} \mathrm{O}-\mathrm{NO}_{3}^{-}$in groundwater samples were measured by the "denitrifying bacteria method" in the Isotope Laboratory of the Chinese Academy of Agricultural Sciences in 2015 (Liu et al., 2017) (Table 2). The stable isotope ratios can be expressed in relation to the international standard values as follows:

$$
\delta_{\text {sample }}(\%)=\left(\frac{R_{\text {sample }}}{R_{\text {standard }}}-1\right) \times 1000
$$

where $R$ is the ratio of ${ }^{15} \mathrm{~N} /{ }^{14} \mathrm{~N}$ or ${ }^{18} \mathrm{O} /{ }^{16} \mathrm{O}$, respectively and $R_{\text {sample }}$ and $R_{\text {standard }}$ are the ratios of the sample and standard ${ }^{15} \mathrm{~N} /{ }^{14} \mathrm{~N}$ and ${ }^{18} \mathrm{O} /{ }^{16} \mathrm{O}$.

\section{Analytical Methods}

\section{Multivariate Statistical Analysis}

PCA is a statistical tool used to identify data and analyze the similarities and differences between data (Jain et al., 2017). Through the method of dimensionality reduction, PCA takes a small number of comprehensive indicators to characterize the research objective (not less than $80 \%$ ) through dimensionality reduction and obtains the components of eigenvalues greater than 1 , defined as the main components (PCs) (BoŠnjak et al., 2012). The KMO value is greater than 0.5, and Bartlett's test has a p-value less than 0.001 , indicating that the data is suitable for factor analysis (Liu et al., 2003). The Kaiser normalized orthogonal rotation were used to obtain the load of each component.

When using the PCA model, the raw data is first converted to a 


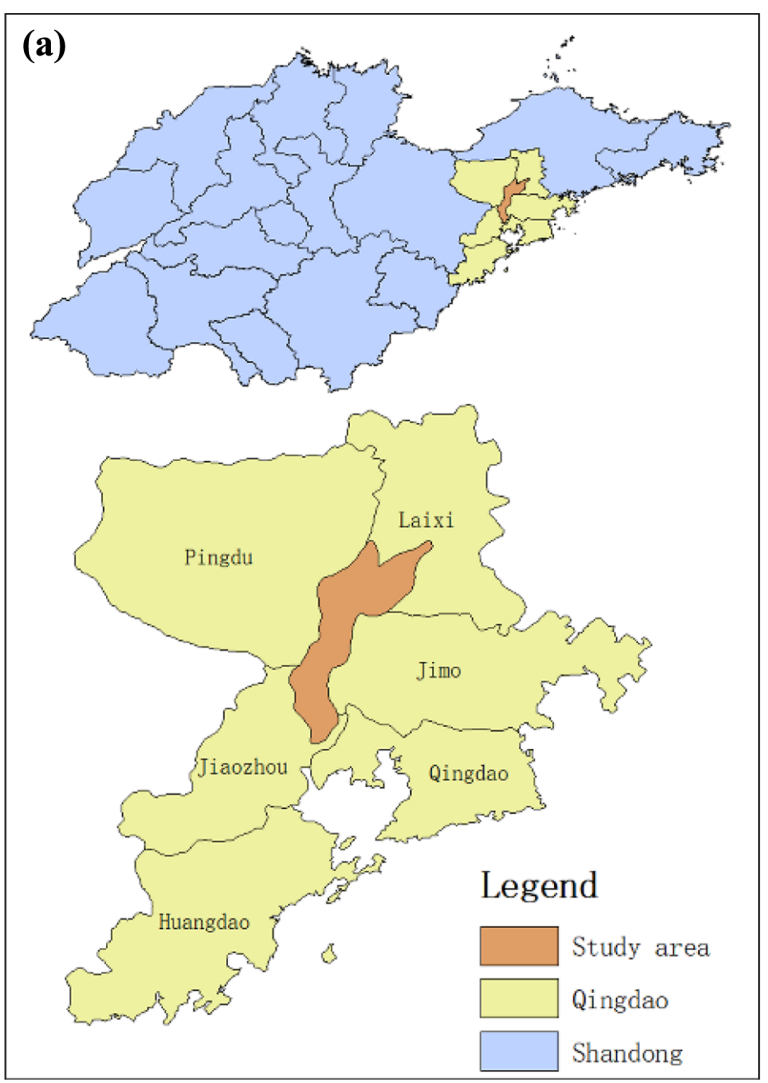

(b)

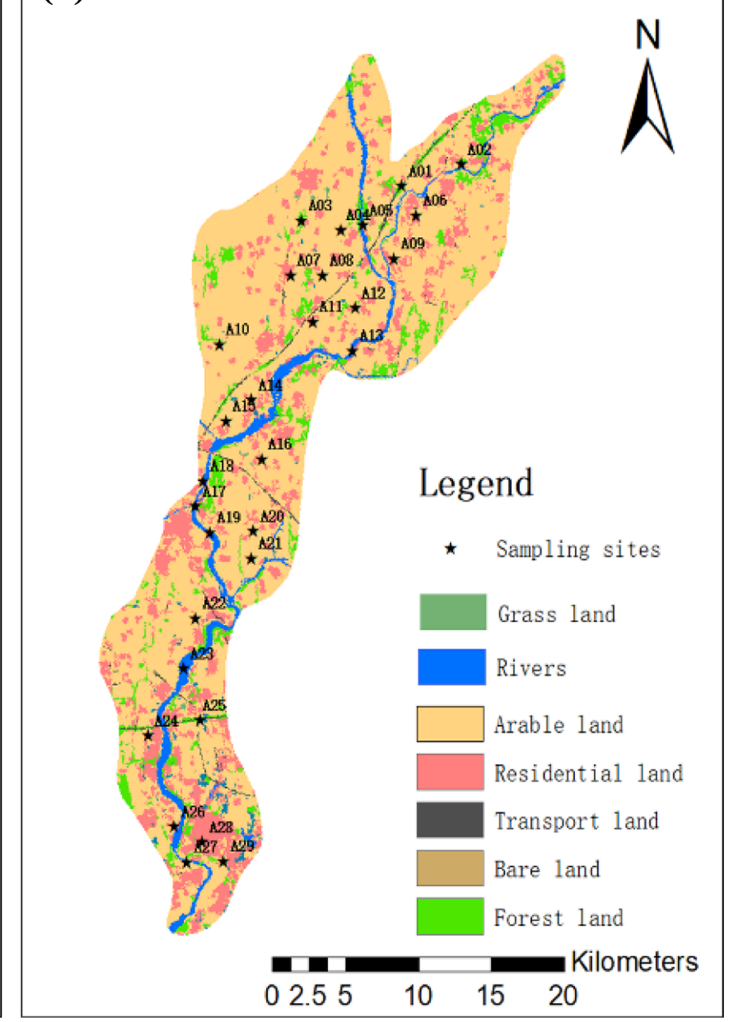

Figure 1. (a) Location of Dagu River Groundwater Source, (b) Locations of monitored wells and land use in the study area.

dimensionless standardized form to eliminate the impact of different dimensions (Jain et al., 2018).

$$
z_{i j}=\frac{c_{i j}-\bar{c}_{i}}{\sigma_{i}}
$$

where $z_{i j}$ is the normalized value; $c_{i j}$ is the concentration of element $i$ in sample $j, i=1,2,3, \ldots, n, j=1,2,3, \ldots, m ; \bar{c}_{i}$ and $\sigma_{\mathrm{i}}$ are the mean concentration and standard deviation for element $i$, respectively.

Then, the PCA model can be expressed as (Li et al., 2000):

$$
z_{i j}=\sum_{k=1}^{p} g_{i k} h_{k j}
$$

where $k=1, \ldots, p$, represents the different sources of pollution, $g_{i k}$ represents the concentration of element $i$ in the pollution source $k$, also known as the factor load and $h_{k j}$ represents the contribution of the pollution source $k$ to the sample $j$, called the factor score.

\section{Bayesian Isotope Mixing Model}

In 2010, SIAR model based on Bayesian equations began to be applied in the field of sources analysis (Parnell et al., 2010). It inputted the isotopic values measured from pollution sources and groundwater sample into the model. The Bayesian equation is used to calculate the contribution rate and posterior distribution characteristics of each pollution source.

The mathematical principle expression of the model is as follows:

$$
X_{i j}=\frac{\sum_{k=1}^{k} p_{k} g_{j k}\left(s_{j k}+c_{j k}\right)}{\sum_{k=1}^{k} p_{k} q_{j k}}+\varepsilon_{i j}
$$

$$
\begin{aligned}
& s_{i j} \sim N\left(\mu_{j k}, \omega_{i j}^{2}\right) \\
& c_{j k} \sim N\left(\lambda_{j k}, \tau_{j k}^{2}\right) \\
& \varepsilon_{i j} \sim N\left(0, \partial_{j}^{2}\right)
\end{aligned}
$$

where $X_{i j}$ represents the value of the $j$ isotope in the $i$ water sample, $i=1,2,3,4, \ldots, n, j=1,2,3, \ldots, j, p_{k}$ is the $k$ source of the pollution contribution rate which is the output of the SIAR model, $q_{j k}$ is the concentration of the isotope $j$ in the $k$ source, $s_{j k}$ represents the value of the $j$ isotope in the $k$ source, $k=1,2,3, \ldots, k$, which obeys the mean $\mu_{j k}$ and the normal distribution of the variance $\omega_{j k}^{2}, c_{j k}$ is the fractionation coefficient for the isotope $j$ on the pollution source $k$ and $\varepsilon_{i j}$ is the residuals representing the remaining unquantified variations in each mixture.

\section{Results and Discussion}

\section{Characteristics of Hydrogeochemistry}

\section{Nitrate Contamination}

According to the monitoring results of the groundwater quality, this area is mainly low mineralized fresh water, the water type is $\mathrm{HCO}_{3}^{-}$ water, and a few locations are $\mathrm{HCO}_{3}^{-}-\mathrm{SO}_{4}^{2-}$ water (Table 1). On the whole, the $\mathrm{NO}_{3}^{-}$pollution in the study area is severe (Fig. 2), and $86.2 \%$ of the groundwater samples exceeds the standard $(20 \mathrm{mg} / \mathrm{L})$. This is because 
Table 1. Monitoring results of the water quality of the Dagu River groundwater source

\begin{tabular}{|c|c|c|c|c|c|c|c|c|c|}
\hline Sites & $\overline{\mathrm{pH}}$ & DO (mg/L) & $\mathrm{NO}_{3}^{-}(\mathrm{mg} / \mathrm{L})$ & $\mathrm{Na}^{+}(\mathrm{mg} / \mathrm{L})$ & $\mathrm{CCa}^{2+}(\mathrm{mg} / \mathrm{L})$ & $\mathrm{Mg}^{2+}(\mathrm{mg} / \mathrm{L})$ & $\mathrm{Cl}^{-}(\mathrm{mg} / \mathrm{L})$ & $\mathrm{HCO}_{3}^{-}(\mathrm{mg} / \mathrm{L})$ & 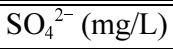 \\
\hline A01 & 7.06 & 6.52 & 133.49 & 34.73 & 156.51 & 36.08 & 71.06 & 15.25 & 139.63 \\
\hline A02 & 7.18 & 3.17 & 52.31 & 32.45 & 124.06 & 22.33 & 41.91 & 213.56 & 133.33 \\
\hline A03 & 7.93 & 4.28 & 22.22 & 38.83 & 99.70 & 23.19 & 46.99 & 289.83 & 87.09 \\
\hline A04 & 7.61 & 10.17 & 160.74 & 46.24 & 205.87 & 34.80 & 91.37 & 106.78 & 140.78 \\
\hline A05 & 7.36 & 9.20 & 77.22 & 58.99 & 242.94 & 28.89 & 175.34 & 244.07 & 208.11 \\
\hline A06 & 7.17 & 3.39 & 43.07 & 68.81 & 135.96 & 29.07 & 106.73 & 366.10 & 94.61 \\
\hline A07 & 7.33 & 6.18 & 70.35 & 31.43 & 95.71 & 17.41 & 50.69 & 76.27 & 34.60 \\
\hline A08 & 6.69 & 8.36 & 127.51 & 48.60 & 157.99 & 41.00 & 76.36 & 144.92 & 121.45 \\
\hline A09 & 7.27 & 4.43 & 70.90 & 39.78 & 99.17 & 30.78 & 53.36 & 91.53 & 133.58 \\
\hline A10 & 7.46 & 9.03 & 115.65 & 35.09 & 189.10 & 21.52 & 62.01 & 137.29 & 138.80 \\
\hline A11 & 6.33 & 4.96 & 45.27 & 41.19 & 85.94 & 22.54 & 73.07 & 152.54 & 66.77 \\
\hline A12 & 7.49 & 8.39 & 108.31 & 38.62 & 137.82 & 33.47 & 58.91 & 228.81 & 81.07 \\
\hline A13 & 7.65 & 4.36 & 63.64 & 27.32 & 96.60 & 25.79 & 47.86 & 91.53 & 86.84 \\
\hline A14 & 6.68 & 7.46 & 99.53 & 31.19 & 188.44 & 25.58 & 120.87 & 152.54 & 118.90 \\
\hline A15 & 7.40 & 8.58 & 116.86 & 43.13 & 203.42 & 38.14 & 97.99 & 228.81 & 149.94 \\
\hline A16 & 7.33 & 9.42 & 100.12 & 42.83 & 180.49 & 35.35 & 84.96 & 251.70 & 88.51 \\
\hline A17 & 7.15 & 7.72 & 124.42 & 45.92 & 178.72 & 40.28 & 98.51 & 152.54 & 110.61 \\
\hline A18 & 7.12 & 6.41 & 105.80 & 46.08 & 153.01 & 20.76 & 86.86 & 198.31 & 74.36 \\
\hline A19 & 6.49 & 3.80 & 53.00 & 40.57 & 88.56 & 36.07 & 60.26 & 45.76 & 188.64 \\
\hline A20 & 6.55 & 4.41 & 72.04 & 46.46 & 113.89 & 38.34 & 59.19 & 122.03 & 165.40 \\
\hline A21 & 6.29 & 9.21 & 120.73 & 24.22 & 188.13 & 15.70 & 75.46 & 228.81 & 95.46 \\
\hline A22 & 7.23 & 3.75 & 59.29 & 36.04 & 130.80 & 27.34 & 58.92 & 289.83 & 68.15 \\
\hline A23 & 7.43 & 4.33 & 48.42 & 93.62 & 143.62 & 30.20 & 161.71 & 350.85 & 65.19 \\
\hline A24 & -- & -- & 78.96 & 26.02 & 132.06 & 17.59 & 55.15 & 221.19 & 79.67 \\
\hline A25 & 7.50 & 8.75 & 12.06 & 39.91 & 159.50 & 21.62 & 102.56 & 282.20 & 129.75 \\
\hline A26 & -- & -- & 0.15 & 23.89 & 31.27 & 12.05 & 34.94 & 114.41 & 58.33 \\
\hline A27 & 6.97 & 2.26 & 21.38 & 69.13 & 113.07 & 39.32 & 87.34 & 434.75 & 103.73 \\
\hline A28 & 7.52 & 2.36 & 37.10 & 48.11 & 119.88 & 23.45 & 90.96 & 289.83 & 63.50 \\
\hline A29 & 7.47 & 0.50 & 2.07 & 152.0 & 121.10 & 46.76 & 157.33 & 549.15 & 256.98 \\
\hline
\end{tabular}

Table 2. Isotopic compositions of groundwater samples in the Dagu River Groundwater source

\begin{tabular}{|c|c|c|c|c|c|}
\hline Sites & $\delta^{15} \mathrm{~N}(\%)$ & $\delta^{18} \mathrm{O}(\%)$ & Sites & $\delta^{15} \mathrm{~N}(\%)$ & $\delta^{18} \mathrm{O}(\%)$ \\
\hline A01 & 10.26 & 4.92 & A13 & 5.45 & 3.73 \\
\hline $\mathrm{A} 02$ & 12.69 & 7.46 & A15 & 7.08 & 5.17 \\
\hline A03 & 9.35 & 6.90 & A16 & 7.45 & 3.30 \\
\hline A04 & 40.98 & 39.19 & A17 & 5.99 & 4.01 \\
\hline A05 & 11.24 & 6.75 & A18 & 31.98 & 29.85 \\
\hline A09 & 6.93 & 4.86 & A23 & 7.96 & 4.89 \\
\hline A 10 & 4.93 & 2.08 & A25 & 1.90 & 4.90 \\
\hline A11 & 15.00 & 6.95 & A27 & 16.96 & 5.54 \\
\hline A12 & 7.74 & 4.37 & A28 & 12.02 & 5.06 \\
\hline A13 & 5.45 & 3.73 & A29 & 41.29 & 26.30 \\
\hline
\end{tabular}

the entire study area is located in the agricultural vegetable base, and local residents apply large amounts of fertilizer to increase vegetable yield. Among them, sampling points with higher $\mathrm{NO}_{3}^{-}$concentration ( 5 times above the standard level) are A01, A04, A08, A10, A12, A15, A16, A17, A18 and A21. Most of these sampling points are located in the upstream of the study area. The reason for this phenomenon is the vegetable planting area in the upstream is larger than that in the downstream. However, A26 and A29 have a very low $\mathrm{NO}_{3}^{-}$ concentration $(0.15$ and $2.07 \mathrm{mg} / \mathrm{L})$, because there are no crops and residents around the sample, A26 located around the forest and A29 


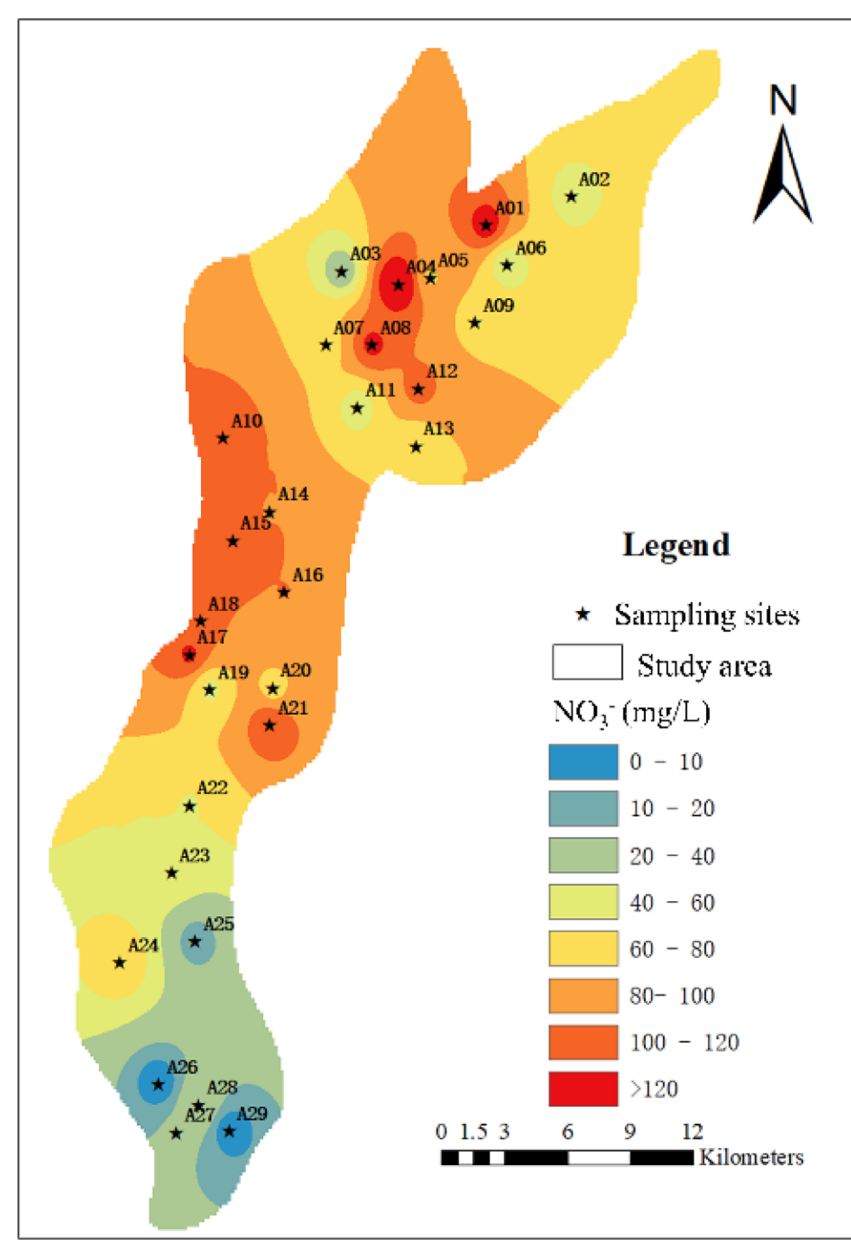

Figure 2. Nitrate concentration interpolation map. was around the abandoned wasteland.

\section{Stable Isotope Compositions}

The variation of $\delta^{15} \mathrm{~N}_{-\mathrm{NO}_{3}}^{-}$and $\delta^{18} \mathrm{O}-\mathrm{NO}_{3}{ }^{-}$in groundwater samples in the study area are large (1.90-40.98\%o and $2.08-39.19 \%$ ) and the mean values are 2.04 and $1.97 \%$ respectively. It indicates the diverse sources of $\mathrm{NO}_{3}^{-}$. The $\delta^{15} \mathrm{~N}_{-} \mathrm{NO}_{3}^{-}$value of $61.9 \%$ sampling points is

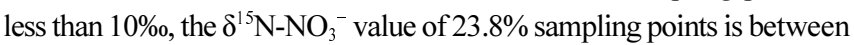
$10-15 \%$, and the $\delta^{15} \mathrm{~N}^{-\mathrm{NO}_{3}}{ }^{-}$values of $14.3 \%$ sampling points (A04, $\mathrm{A} 18$ and A29) is relatively high $(40.98,31.98$ and 41.29$)$. The $\delta^{18} \mathrm{O}-$ $\mathrm{NO}_{3}{ }^{-}$values of 18 sampling points ranged from 0 to $10 \%$, while the $\delta^{18} \mathrm{O}_{-} \mathrm{NO}_{3}{ }^{-}$value are higher at the other three sampling points (A04, A18 and A29) in Table 2. Since the $\mathrm{NO}_{3}{ }^{-}$concentrations at the A04 and $\mathrm{A} 08$ are also high, it can be concluded that the abnormal values of the two points come from multiple sources of pollution. The extremely low $\mathrm{NO}_{3}^{-}$concentration at the A29 shows that denitrification may have occurred at this point.

In general, the values of $\delta^{15} \mathrm{~N}_{-} \mathrm{NO}_{3}{ }^{-}$and $\delta^{18} \mathrm{O}-\mathrm{NO}_{3}{ }^{-}$in groundwater can reveal the sources of $\mathrm{NO}_{3}^{-}$pollution and the denitrification process of the groundwater system in the study area (Kellman and Hillaire-Marcel, 1998; Pardo et al., 2004). The sources of $\mathrm{NO}_{3}^{-}$is related to the nitrogen cycle and the isotope fractionation will bias the values of $\delta^{15} \mathrm{~N}$ $\mathrm{NO}_{3}{ }^{-}$and $\delta^{18} \mathrm{O}-\mathrm{NO}_{3}{ }^{-}$. Thus, the effect of denitrification becomes significant (Teppei et al., 2003; Xue et al., 2009), and it is important to identify the denitrification reaction for the analysis of the sources pollution. When the slope between $\delta^{15} \mathrm{~N}_{-} \mathrm{NO}_{3}{ }^{-}$and $\delta^{18} \mathrm{O}-\mathrm{NO}_{3}{ }^{-}$is between 1.3:1 and 2:1, the denitrification process occurs in the system (Aravena and Robertson, 2010; Xue et al., 2012; Xing and Liu, 2016). According to the groundwater isotope data, the values of $\delta^{15} \mathrm{~N}^{-N_{3}}{ }_{3}^{-}$ and $\delta^{18} \mathrm{O}_{-} \mathrm{NO}_{3}^{-}$in groundwater are linear with a slope of 0.827 (Fig. 3 ). It can be seen that there is no obvious denitrification reaction in the groundwater of the study area.

\section{Sources Analysis}

\section{Principal Component Analysis}

To study the sources of $\mathrm{NO}_{3}^{-}$in the groundwater of the Dagu River, the principal component analysis was carried out on the original data of 10 hydrochemistry components $\left(\mathrm{pH}, \mathrm{DO}, \mathrm{NO}_{3}^{-}\right.$, $\mathrm{NH}_{4}^{+}, \mathrm{Na}^{+}, \mathrm{Ca}^{2+}, \mathrm{Mg}^{2+}, \mathrm{Cl}^{-}, \mathrm{HCO}_{3}^{-}$and $\mathrm{SO}_{4}{ }^{2-}$ ) from the sampling sites $(\mathrm{n}=29)$. The result shows that the contribution of the first four PCs is 32.6, $27.3,13.1$ and $11.7 \%$, respectively, covering more than $84.7 \%$ of the total data (Fig. 4). Fig. 5 shows the relationship between 10 water chemistry parameters and 4 PCs. The larger the projection of the parameter on the axis, the greater the load of the parameter in the PC. The parameters on the same side of the $\mathrm{x}$ axis or $\mathrm{y}$ axis indicate a posi45 tive correlation between these parameters (e.g. $\mathrm{Mg}^{2+}, \mathrm{Cl}^{-}$and $\mathrm{SO}_{4}{ }^{2-}$ ) and a negative correlation for the other cases (e.g. $\mathrm{HCO}_{3}^{-}$and $\mathrm{NO}_{3}^{-}$). Fig. 6 shows the load of the 10 water chemistry param-

Figure 3. Crossplot of $\delta^{15} \mathrm{~N}-\mathrm{NO}_{3}^{-}$and $\delta^{18} \mathrm{O}-\mathrm{NO}_{3}^{-}$values in the groundwater samples. 


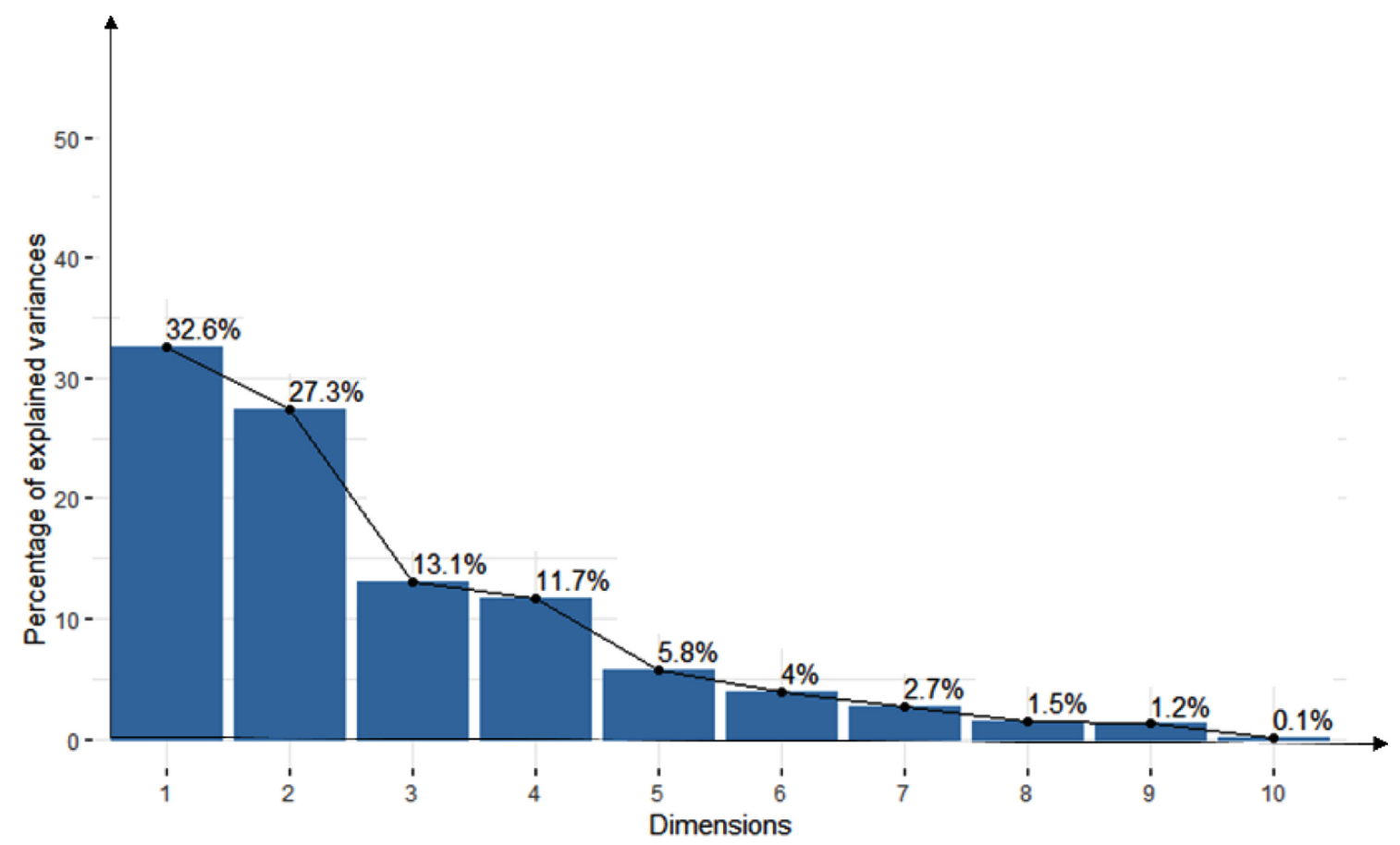

Figure 4. Principal component analysis results of 10 water chemical parameters at sampling points (n=29): principal component interpretation variance percentage Scree plot.

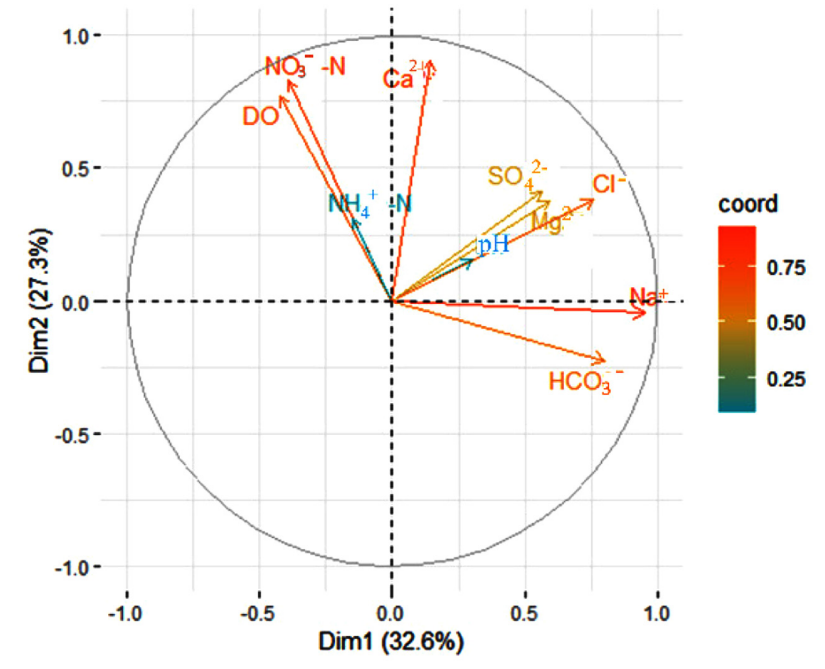

a

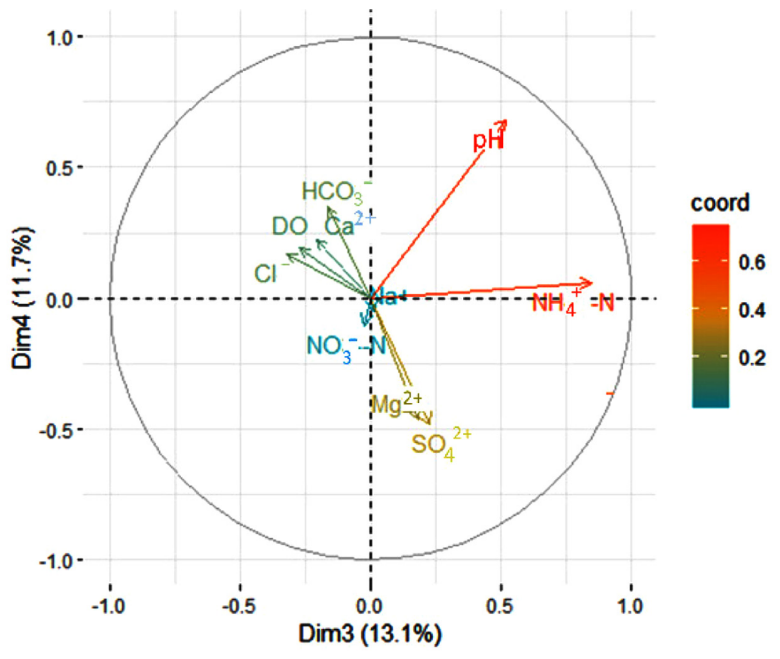

b

Figure 5. Principal component analysis results of 10 water chemical parameters at sampling points (n=29): (a) Correlation load map of 10 water chemical parameters on PC 1 and PC 2, respectively, (b) Correlation load map of 10 water chemical parameters on PC 3 and PC 4, respectively.

eters on the first 4 principal components. According to the principle that the load is not less than 0.5 (BoŠnjak et al., 2012), the variables explained by each principal component are selected.

In $\mathrm{PC} 1, \mathrm{Na}^{+}, \mathrm{Mg}^{2+}, \mathrm{Cl}^{-}, \mathrm{SO}_{4}{ }^{2-}$ and $\mathrm{HCO}_{3}{ }^{-}$are large loads, and they are positively related to each other (Fig. 4). They are the main ionic components in groundwater and are related to the salt content of groundwater, which may come from mineral dissolution and cation exchange in the soil (Panno et al., 2001). Brink et al. (2007) indicated that the infiltration of domestic sewage is accompanied by the enrichment of solutes $\left(\mathrm{Na}^{+}, \mathrm{Mg}^{2+}, \mathrm{Cl}^{-}\right.$and $\left.\mathrm{HCO}_{3}^{-}\right) . \mathrm{Cl}^{-}$is considered as a stable tracer not subject to changes in $\mathrm{NO}_{3}^{-}$content and its potential sources are industrial, domestic sewage and manure. The study area is mainly located at the place of agricultural activities, and the application of farm manure will increase the $\mathrm{Cl}^{-}$content in the groundwater (Meghdadi and Javar, 2018). To conclude, the source of pollution may be manure or sewage. In $\mathrm{PC} 2, \mathrm{DO}, \mathrm{NO}_{3}{ }^{-}$and $\mathrm{Ca}^{2+}$ have the greatest effect with loads of $0.7697,0.8299$ and 0.9076 , respectively (Table 3 ). The strong correlation between $\mathrm{DO}$ and $\mathrm{NO}_{3}{ }^{-}$indicates that the concentration of $\mathrm{NO}_{3}{ }^{-}$in groundwater may be affected by the redox environment. These ions are closely related to solutes produced by anthropogenic activities, 
Table 3. Loads of the 10 water chemical parameters on the first 4 principal components

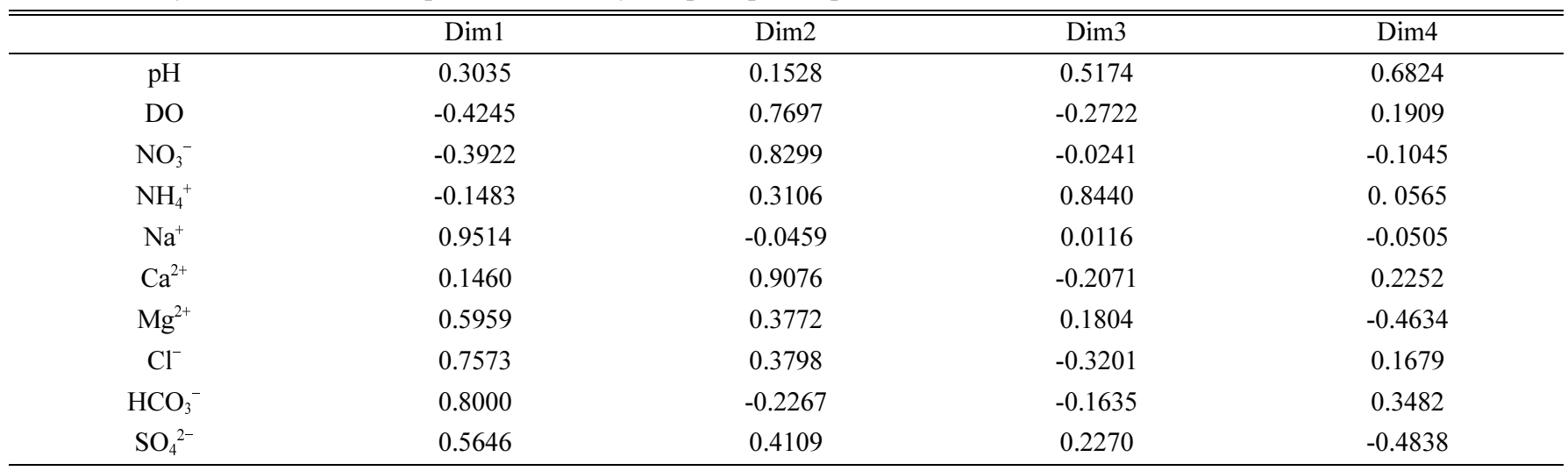

such as domestic sewage and fertilizers (Ioannis et al., 2016; Wang et al., 2017). We took samples during the irrigation period (April). Thus the nitrogen in the soil may infiltrate into the groundwater through irrigation and leaching. In addition, the local farmers use chemical fertilizer (calcium nitrate) for a long time resulting in the acidification of soil and increase the content of $\mathrm{Ca}^{2+}$ in groundwater. Thus, it could come from soil $\mathrm{N}$, sewage and $\mathrm{NO}_{3}^{-}$fertilizer.

The $\mathrm{pH}$ loads in the PC 3 and PC 4 were large, 0.5174 and 0.6824, respectively. The load of $\mathrm{NH}_{4}{ }^{+}$in the main component 3 was 0.8440 (Table 3). The locations of Pingdu and Laixi in the upper and middle reaches of the Dagu River are known as the "hometowns of vegetables". To enhance soil fertility and increase vegetable yield, the people used a large amount of nitrogen fertilizer, thereby increasing the $\mathrm{pH}$ and $\mathrm{NH}_{4}{ }^{+}$content of local groundwater. Thus, the source may be inorganic fertilizer (ammonium fertilizer).

In summary, the pollution sources analyzed by PCA mainly include sewage, inorganic fertilizer $\left(\mathrm{NO}_{3}{ }^{-}\right.$fertilizer, ammonium fertilizer), manure and soil N. However, the contribution rate of each PC only represents the sum of all possible similar sources of pollution, not the contribution rate of a particular source.

\section{Stable Isotope Analysis in $R$}

From Fig. 6, it can be found that $33 \%$ of the sampling points (A01, A02, A03, A05, A11, A27 and A28) fall in the overlapping area of manure and sewage. The sampling period took place during a stage with the utilization of a large amount of fertilization and most villages in the study area have not effectively treat the sewage. Hence, manure and sewage are likely to be sources in those points. The sampling point (A25) falls at the overlap of the two sources, soil $\mathrm{N}$ and $\mathrm{NH}_{4}{ }^{+}$Fertilizer \& Precipitation. Appelo and Postma (2006) declare that the concentration of $\mathrm{NO}_{3}{ }^{-}$from soil $\mathrm{N}$ ranges from 0.062 to 12.4 $\mathrm{mg} / \mathrm{L}$. Since the $\mathrm{NO}_{3}{ }^{-}$concentration in A25 is lower than $12.4 \mathrm{mg} / \mathrm{L}$ (Table 1), it is believed that the $\mathrm{NO}_{3}^{-}$pollution in $\mathrm{A} 25$ may come from soil N. Besides, $47 \%$ of sampling points locate at the intersection of the four pollution sources (manure, sewage, soil $\mathrm{N}$ and $\mathrm{NH}_{4}{ }^{+}$Fertilizer \& Precipitation). Besides A26 with $\mathrm{NO}_{3}{ }^{-}$concentration below 10 $\mathrm{mg} / \mathrm{L}$, other sampling points are enriched in the concentration of $\mathrm{NO}_{3}^{-}$. A26 is located close to town area, so its source of $\mathrm{NO}_{3}{ }_{3}^{-}$is likely to be sewage. However, other sampling points are difficult to distinguish for the main source of pollution. Because they are distributed

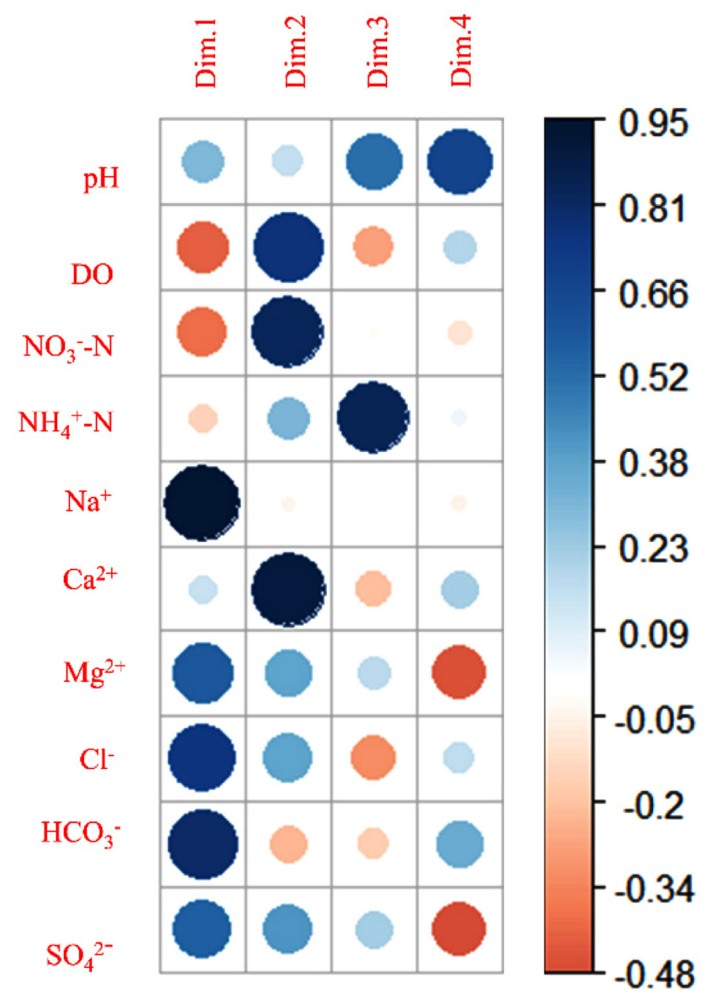

Figure 6. Principal component analysis results: load diagrams of 10 water chemical parameters on the 4 PCs.

throughout the study area and there is a mixtures of activities, which makes it difficult to specify a single source of $\mathrm{NO}_{3}{ }^{-}$pollution.

However, 14\% of the sampling points (A04, A18 and A29) does not fall within the scope of any sources of pollution. Since the content of $\mathrm{NO}_{3}^{-}$in $\mathrm{A} 04$ and $\mathrm{A} 18$ is high and the land use type in the study area is mainly arable land, the reason for the high values of $\delta^{15} \mathrm{~N}_{-} \mathrm{NO}_{3}{ }^{-}$and $\delta^{18} \mathrm{O}_{-} \mathrm{NO}_{3}{ }^{-}$in these two points is that they may come from multiple pollution sources (Table 1 and 2). Kendall (1998) pointed out that the denitrification process is accompanied with a decrease in $\mathrm{NO}_{3}{ }^{-}$con-

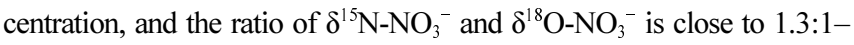
2:1. Therefore, denitrification reaction may occur at A29 (1.57:1). In addition, there is no sampling points falling in $\mathrm{NO}_{3}{ }^{-}$fertilizer and $\mathrm{NO}_{3}{ }^{-}$precipitation. This may be due to isotope fractionation.

To summary, the potential sources of contamination by SIAR are 
Table 4. SIAR result: contribution rates of nitrate pollution sources

\begin{tabular}{ccccc}
\hline \hline Source & Min & Max & Mode & Mean \\
\hline Manure & 0 & 0.902 & 0.381 & 0.377 \\
Sewage & 0 & 0.991 & 0.330 & 0.329 \\
Soil N & 0 & 0.942 & 0.303 & 0.294 \\
\hline
\end{tabular}

manure (37.7\%), sewage (32.9\%) and soil N (29.4\%), in Table 4. However, due to the biochemical reactions and interaction of multiple sources of pollution, it is impossible to accurately determine the sources of $\mathrm{NO}_{3}^{-}$contamination in the study area.

\section{Combination of PCA and SIAR}

By comparing the analyzed results of PCA and SIAR, we can see that both methods have advantages and disadvantages. The PCA is superior to the SIAR in judging the sources of pollution, while the SIAR performs better in calculating the contribution rates. Therefore, the results of PCA are selected as the pollution sources in the study area. The sources of $\mathrm{NO}_{3}^{-}$have sewage, inorganic fertilizer $\left(\mathrm{NO}_{3}{ }^{-}\right.$fertilizer, $\mathrm{NH}_{4}{ }^{+}$fertilizer), manure and soil $\mathrm{N}$ in the study area. Then, SIAR can be used to quantitatively estimate the contribution rate of the each potential source of $\mathrm{NO}_{3}{ }^{-}$in the study area. Since obvious denitrification did not occur in this region (expect A29, in which may have a weak biochemical effect, but it will not have a significant impact on the isotopic composition), we assume the isotope fractionation coefficient $\left(c_{j k}\right)$ is 0 . The results of SIAR explain the differences of contribution rates of five pollution sources in the groundwater source of Dagu River (Fig. 7). The horizontal axis of the graph represents the contribution rates of all the pollution sources, and the vertical axis indicates the occurrence frequencies of each pollution source contribution rate in the study area.

Combined with Table 5 and Fig. 7, it can be concluded that the contribution of manure, $\mathrm{NO}_{3}^{-}$fertilizer and sewage is roughly normal distribution. Their posterior distribution ranges are $2.0-50.4 \%, 10.3-$ $44.4 \%, 0-42.3 \%$ and their average values are $27.3,27.7$ and $21.8 \%$, respectively. However, the distribution of soil $\mathrm{N}$ and $\mathrm{NH}_{4}{ }^{+}$fertilizer \& precipitation pollution sources is asymmetric. Their posterior distribution ranges are $0-30.9 \%, 0-26.3 \%$, and their mean values are 13.0 and $10.2 \%$. This may be due to different land use types or different fertilization conditions at various sampling points. Therefore, the contribution rate of $\mathrm{NO}_{3}{ }^{-}$fertilizer and manure are the highest 27.7 and $27.3 \%$, respectively, followed by sewage (21.8\%), soil $\mathrm{N}(13.0 \%)$, and $\mathrm{NH}_{4}{ }^{+}$fertilizer \& precipitation (10.2\%). However, it is worth noticing that the contribution of $\mathrm{NH}_{4}^{+}$fertilizer \& precipitation is lower than that of soil nitrogen, probably because ammonium ions are easily adsorbed and the sampling time is dry season (Yu et al., 2018).

In general, this mixed method is preferred clearing pollution sources and contribution rates. The result reveals that manure and fertilizer $\left(\mathrm{NO}_{3}{ }^{-}\right.$fertilizer and $\mathrm{NH}_{4}{ }^{+}$fertilizer \& precipitation) are the main $\mathrm{NO}_{3}{ }^{-}$ sources in the study area, with the contribution rate 27.3 and $37.9 \%$. And this is consistent with the type of land use in the study area.

\section{Conclusions}

Through the analysis in this paper, we make conclusion as follows: (1) the pollution sources analyzed by PCA include manure, sewage, $\mathrm{NO}_{3}{ }^{-}$fertilizer, $\mathrm{NH}_{4}{ }^{+}$fertilizer and soil $\mathrm{N}$, while they only include manure, sewage and soil $\mathrm{N}$ according to SIAR. Due to the effects of

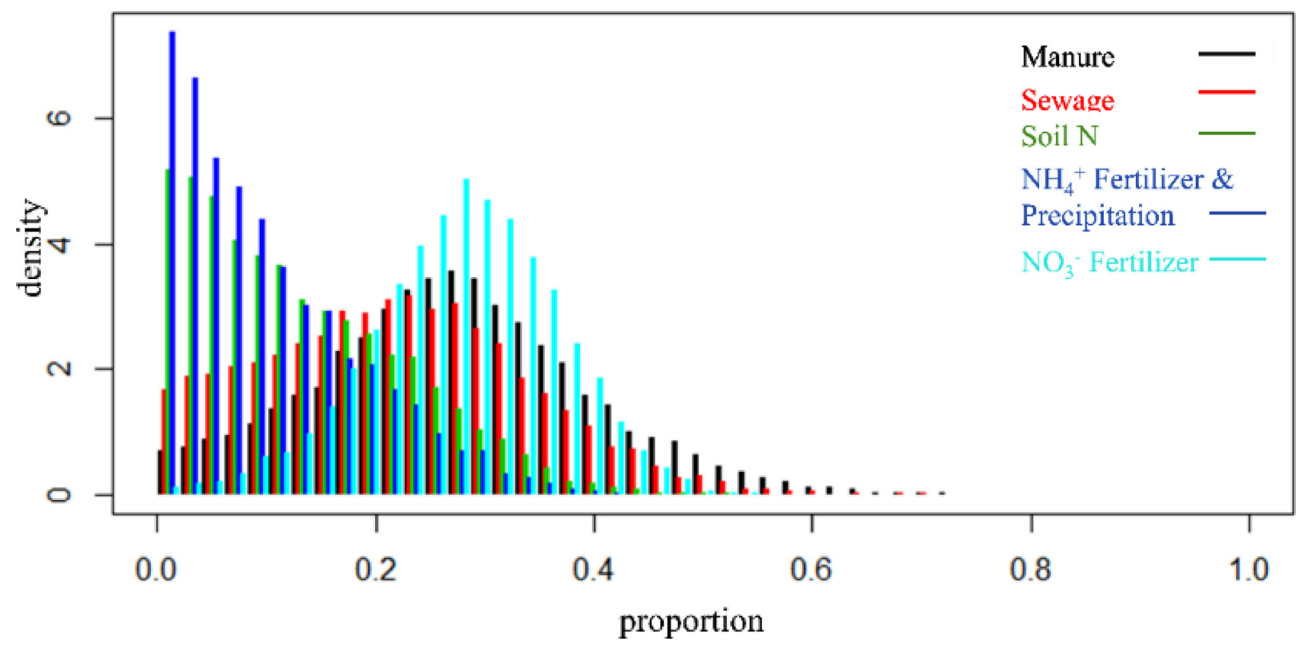

Figure 7. Distribution of the contribution rate of each pollution source.

Table 5. The mixed method result: contribution rates of nitrate pollution sources

\begin{tabular}{ccccc}
\hline \hline Source & Min & Max & Mode & Mean \\
\hline Manure & 0.020 & 0.504 & 0.280 & 0.272 \\
Sewage & 0 & 0.423 & 0.230 & 0.218 \\
Soil N & 0 & 0.310 & 0.03 & 0.130 \\
$\mathrm{NH}_{4}^{+}$Fertilizer \& Precipitation & 0 & 0.263 & 0.022 & 0.102 \\
$\mathrm{NO}_{3}^{-}$Fertilizer & 0.103 & 0.444 & 0.280 & 0.277 \\
\hline
\end{tabular}


biochemical process and multiple pollution sources on the isotopic fraction, SIAR is not suitable to analyze the pollution source types in the study area; (2) the contribution rates determined by SIAR for manure, sewage and soil $\mathrm{N}$ are $37.7,32.9$ and $29.4 \%$, respectively. However, PCA can only get the sum of contribution rates of related pollution sources so it is not able to accurately capture the contribution rate of each source; (3) according to the combination method of PCA and SIAR, the contribution rates of $\mathrm{NO}_{3}^{-}$fertilizer, manure, sewage, soil N, $\mathrm{NH}_{4}{ }^{+}$fertilizer \& precipitation are 27.7, 27.3, 21.8, 13.0 and $10.2 \%$, respectively. The results is in accord with the real hydrogeologic conditions in the study area. The results of the study provide clear evidence for a significant influence of different pollution sources on the groundwater in Shandong Peninsula Agricultural Area. Hence, to reduce the regional $\mathrm{NO}_{3}{ }^{-}$pollution, the usage of fertilizer should be decreased and the absorption rate is preferred increasing. Sewage pipes should be built in the countryside. Furthermore, changing crop cultivation methods can also make full use of mineral elements in different strata.

\section{Acknowledgements}

This study was supported by the National Program on the Key Project of Natural Science Foundation of China, NSFC (41731280).

\section{References}

Appelo, C.A.J., and Postma, D., 2006, Geochemistry: Groundwater and Pollution (2nd edition). Leiden, Rotterdam the Netherlands: Balkema, $649 \mathrm{p}$.

Aravena, R., and Robertson, W.D., 2010, Use of Multiple Isotope Tracers to Evaluate Denitrification in Ground Water: Study of Nitrate from a Large-Flux Septic System Plume. Groundwater, v. 36, pp. 975-982.

Baily, A., Rock, L., Watson, C.J., Fenton, O., 2011, Spatial and temporal variations in groundwater nitrate at an intensive dairy farm in southeast Ireland: Insights from stable isotope data. Agriculture, Ecosystems and Environment, v. 144, pp. 308-318.

BoŠnjak, M.U., Capak, K., Jazbec, A., Casiot, C., Sipos, L., Dadić, Ž., 2012, Hydrochemical characterization of arsenic contaminated alluvial aquifers in Eastern Croatia using multivariate statistical techniques and arsenic risk assessment. Science of the Total Environment, v. 420, pp. 100-110.

Brink, C.V.D., Frapporti, G., Griffioen, J., Zaadnoordijk, W.J., 2007, Statistical analysis of anthropogenic versus geochemical-controlled differences in groundwater composition in The Netherland. Journal of Hydrology, v. 336, pp. 470-480.

Burns, D.A., Boyer, E.W., Elliott, E.M., Carol, K., 2009, Sources and Transformations of Nitrate from Streams Draining Varying Land Uses: Evidence from Dual Isotope Analysis. Journal of Environmental Quality, v. 38, pp. 1149-1159.

Chang, C.C., Kendall, C., Silva, S.R., Silva, S.R., Battaglin, W.A., Campbell, D.H., 2002, Nitrate stable isotopes: tools for determining nitrate sources among different land uses in the Mississippi River Basin. Canadian Journal of Fisheries and Aquatic Sciences, v. 59, pp, 18741885.

Fang, Y.H., Zheng, X.L., Peng, H., Wang, H., 2018, Groundwater quality evaluation based on fuzzy synthetic evaluation and variable fuzzy sets. Journal of Environmental Science, v. 38, pp. 546-552 (in Chinese).

Ghaeminia, M., and Nader, M., 2018, Remediation of nitrate-contaminated groundwater by PRB-Electrokinetic integrated process. Journal of Environmental Management, v. 222, pp. 234-241.

Ioannis, M., 2016, Nitrate source identification in groundwater of multiple land-use areas by combining isotopes and multivariate statistical analysis: A case study of Asopos basin (Central Greece). Science of the Total Environment, v. 541, pp. 802-814.

Jain, S., Sharma, S.K., Choudhary, N., Masiwal, R., Saxena, M., Sharma, A., Mandal, T.K., Gupta, A., Gupta, N.C., Sharma, C., 2017, Chemical characteristics and source apportionment of PM 2.5 using PCA/APCS, UNMIX, and PMF at an urban site of Delhi, India. Environmental Science \& Pollution Research, v. 24, pp. 1-20.

Jain, S., Sharma, S.K., Mandal, T.K., Saxena, M., 2018, Source apportionment of PM 10 in Delhi, India using PCA/APCS, UNMIX and PMF. Particuology, v. 37, pp. 107-118.

Jin, Z.F., Pan, Z.Y., Jin, M.T., Li, F.L., Wan, Y., Gu, B., 2012, Determination of nitrate contamination sources using isotopic and chemical indicators in an agricultural region in China. Agriculture, Ecosystems and Environment, v. 155, pp. 78-86.

Kendall, C., 1998, Tracing nitrogen sources and cycling in catchments. In Isotope Tracers in Catchment Hydrology. Kendall, C., Mcdonnell, J.J., Eds. Elsevier Science B.V., Amsterdam. pp. 519-576.

Kaown, D., Koh, D.C., Mayer, B., Lee, K.K., 2009, Identification of nitrate and sulfate sources in groundwater using dual stable isotope approaches for an agricultural area with different land use (Chuncheon, mid-eastern Korea). Agriculture, Ecosystems and Environment, v. 132, pp. 223-231.

Kaushal, S.S., Groffman, P.M., Band, L.E., Elliott, E.M., Shields, C.A., Kendall, C., 2011, Tracking nonpoint source nitrogen pollution in human-impacted watersheds. Environmental Science \& Technology, v. 45 , pp. $8225-8232$.

Kellman, L., Hillaire-Marcel, C., 1998, Nitrate cycling in streams: using natural abundances of $\delta^{15} \mathrm{~N}^{-\mathrm{NO}_{3}}{ }^{-}$to measure in-situ denitrification. Biogeochemistry, v. 43, pp. 273-292.

Kim, K.H., Yun, S.T., Mayer, B., Lee, J.H., Kim, T.S., Kim, H.K., 2015, Quantification of nitrate sources in groundwater using hydrochemical and dual isotopic data combined with a Bayesian mixing model. Agriculture Ecosystems \& Environment, v. 199, pp. 369-381.

Lee, J.Y., Kwon, K.D., Park, Y.C., Jeon, W.H., 2017, Unexpected nationwide nitrate decline in groundwater of Korea. Hydrological Processes, v. 31, pp. 4693-4704.

Li, C., Li, S.L., Yue, F.J., Liu, J., Zhong, J., Yan, Z.F., Zhang, R.C., Wang, Z.J., Xu, S., 2019, Identification of sources and transformations of nitrate in the Xijiang River using nitrate isotopes and Bayesian model. Science of the Total Environment, v. 646, pp. 801-810.

Li, W.H., Yue, H.H., Valle-Cervantes, S., Qin, S.J., 2000, Recursive PCA for adaptive process monitoring. Journal of Process Control, v. 10, pp. 471-486.

Liu, C.W., Lin, K.H., Kuo, Y.M., 2003, Application of factor analysis in the assessment of groundwater quality in the blackfoot disease area in Taiwan. Science of the Total Environment, v. 313, pp. 77-89.

Liu, G.Q., Zhou, S.Y., Huang, X.D., Wang, T., Xu, D., Yue, C.D., 2017, Multiple methods to recognize sources of underground water nitrate contamination in plain area of Dagu River, Qingdao, China. Journal of Environmental Science, v. 37, pp. 347-356 (in Chinese).

Liu, J., Shen, Z.Y., Yan, T.Z., Yang, Y.C., 2018, Source identification and impact of landscape pattern on riverine nitrogen pollution in a typical urbanized watershed, Beijing, China. Science of the Total Environment, v. 628-629, pp. 1296-1307.

Ma, Z.F., Yang, Y., Lian, X.Y., Jiang, Y.J., Xi, B.D., Peng, X., Yan, K., 2016, Identification of nitrate sources in groundwater using a stable isotope and 3DEEM in a landfill in Northeast China. Science of the Total Environment, v. 563, pp. 593-599.

Matiatos, I., Alexopoulos, A., Godelitsas, A., 2014, Multivariate statistical analysis of the hydrogeochemical and isotopic composition of the groundwater resources in northeastern Peloponnesus (Greece). Science of the Total Environment, v. 476-477, pp. 577-590.

Matiatos, I., 2016, Nitrate source identification in groundwater of multiple 
land-use areas by combining isotopes and multivariate statistical analysis: A case study of Asopos basin (Central Greece). Science of the Total Environment, v. 541, pp. 802-814.

Meghdadi, A., Javar, N., 2018, Quantification of spatial and seasonal variations in the proportional contribution of nitrate sources using a multiisotope approach and Bayesian isotope mixing model. Environmental Pollution, v. 235, pp. 207-222.

Pardo, L.H., Kendall, C., Pett-Ridge, J., Chang, C.C.Y., 2004, Evaluating the source of streamwater nitrate using $\delta^{15} \mathrm{~N}$ and $\delta^{18} \mathrm{O}$ in nitrate in two watersheds in New Hampshire, USA. Hydrological Processes, v. 18, pp. 2699-2712.

Parnell, A.C., Inger, R., Bearhop, S., Jackson, A.L., 2010, Source partitioning using stable isotopes: coping with too much variation. Plos One, v. 5, e 9672.

Panno, S.V., Hackley, K.C., Hwang, H.H., Kelly, W.R., 2001, Determination of the sources of nitrate contamination in karst springs using isotopic and chemical indicators. Chemical Geology, v. 179, pp. 113-128.

Pastén-Zapata, E., Ledesma-Ruiz, R., Harter, T., Ramirez, A., Mahlknecht, J., 2014, Assessment of sources and fate of nitrate in shallow groundwater of an agricultural area by using a multi-tracer approach. Science of the Total Environment, v. 470, pp. 855-864.

Yu, Q.B., Wang, F., Li, X.Y., Yan, W.J., Li, Y.Q., Lv, S.C., 2018, Tracking nitrate sources in the Chaohu Lake, China, using the nitrogen and oxygen isotopic approach. Environmental Science and Pollution Research, v. 25, pp. 19518-19529.

Raza, M., Lee, J.Y., 2019, Factors affecting spatial pattern of groundwater hydrochemical variables and nitrate in agricultural region of Korea. Episodes, v. 42, pp. 135-148.

Rebolledo, B., Gil, A., Flotats, X., Sanchez, J.A., 2016, Assessment of groundwater vulnerability to nitrates from agricultural sources using a GIS-compatible logic multicriteria model. Journal of Environmental Management, v. 171, pp. 70-80.

Teppei, F., Hiscock, K.M., Dennis, P.F., Grischek, T., 2003, A dual isotope approach to identify denitrification in groundwater at a river-bank infiltration site. Water Research, v. 37, pp. 3070-3078.

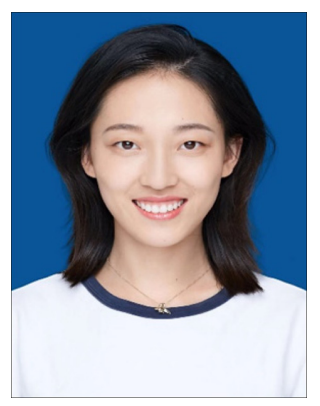

Ruyu Yuan is a master student of college of Environmental Science and Engineering at Ocean University of China. Her research has been concerned with groundwater pollution control and remediation, with interest in pollution sources analysis.

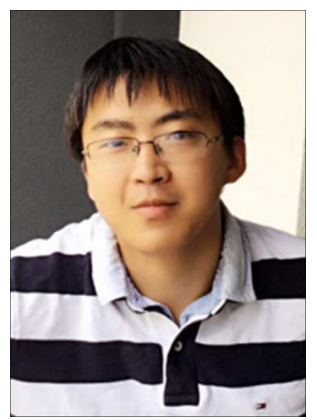

Tianyuan Zheng is a Postdoc of Ocean University of China. He did his ph.D in Helmholtz Centre for Environmental Research and Technical University of Dresden. He is specialized in the field of numerical modeling of multiphase flow, thermo-hydro-mechanical freezing process and density flow coupled with reactive transport. He was deeply involved in the development of open source finite element software OpenGeoSys (OGS). He has published over 20 research papers in international journals.
Wang, S., Zheng, W., Currell, M., Currell, M., Yang, Y.H., Zhao, H., Lv, M.Y., 2017, Relationship between land-use and sources and fate of nitrate in groundwater in a typical recharge area of the North China Plain. Science of the Total Environment, v. 609, pp. 607-620.

Wang, L.Y., Zheng, X.L., Tian, F.F., Xin, J., Nei, H., 2018, Soluble organic nitrogen cycling in soils after application of chemical/organic amendments and groundwater pollution implications. Journal of Contaminant Hydrology, v. 217, pp. 43-51.

Widory, D., Kloppmann, W., Chery, L., Bonnin, J., Rochdi, H., Guinamant, J.L., 2004, Nitrate in groundwater: an isotopic multi-tracer approach. Journal of Contaminant Hydrology, v. 72, pp. 165-188.

Xing, M., and Liu, W.G., 2016, Using dual isotopes to identify sources and transformations of nitrogen in water catchments with different land uses, Loess Plateau of China. Environmental Science \& Pollution Research, v. 23, pp. 1-14.

Xue, D.M., De, B.B., Van, C.O., Hennessy, C., Berglund, M., Boeckx, P., 2012, Use of a Bayesian isotope mixing model to estimate proportional contributions of multiple nitrate sources in surface water. Environmental Pollution, v. 161, pp. 43-49.

Xue, D.M., Jorin, B., Bernard, D.B., Accoe, F., Neatler, A., Taylor, P., Cleemput, O.V., Berglund, M., Boeckx, P., 2009, Present limitations and future prospects of stable isotope methods for nitrate source identification in surface- and groundwater. Water Research, v. 43, pp. 1159-1170.

Xue, D.M., Pang, F.M., Meng, F.Q., Wang, Z.L., Wu, W.L., 2015, Decision-tree-model identification of nitrate pollution activities in groundwater: a combination of a dual isotope approach and chemical ions. Journal of Contaminant Hydrology, v. 180, pp. 25-33.

Zhao, J.C., Li, Y.Z., Ichiji, Y.S., Xu, C.Y., Li, Q.Z., Jia, X.F., 2010, Summary on Deduction and Trace the Source Methods for Ground Water Nitrate Contamination. Chinese Agricultural Science Bulletin, v. 26, pp. 374-378 (in Chinese).

Zhao, T.K., Zhang, C.J., Du, L.F., Liu, B.C., An, Z.Z., 2007, Investigation on Nitrate Concentration in Groundwater in Seven Provinces (City) Surrounding the Bo-Hai Sea. Journal of Agricultural Environmental Science, v. 26, pp. 779-783 (in Chinese).

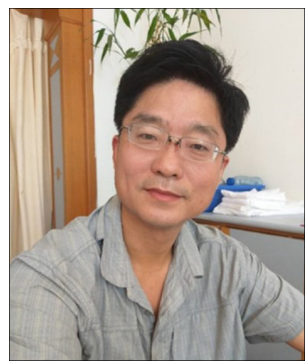

Xilai Zheng is a Professer of Ocean University of China. He has published over 200 research papers in international and Chinese journals. His research interests involve groundwater pollution theory and remediation technology, development, utilization and protection of coastal water resources. He is in charge of the national natural science foundation of China, the joint key fund of the national foundation of China and Shandong province and so on

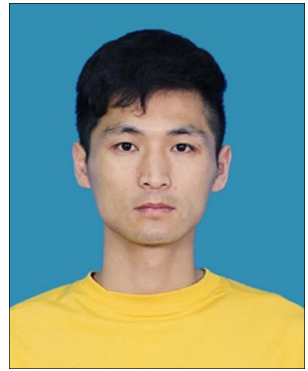

Dongsheng Liu is a postdoctor of Eco-Environmental Research Department, Nanjing Hydraulic Research Institute, China. His research interests involve Engineering Seepage and Groundwater Environment. 


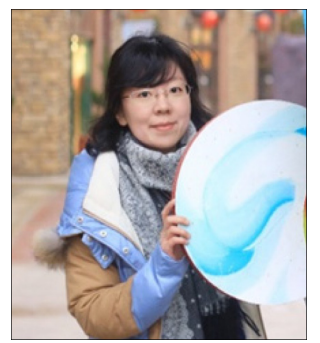

Jia Xin is an associate professor of Ocean University of China. Her research is focused on pollution mechanism and remediation technologies for soil and groundwater. Specific research interests include: 1) Environmental behaviors of emerging contaminant in porous media; 2) Nitrogen cycling in soil and groundwater. She has published nearly 30 research papers in international journals.

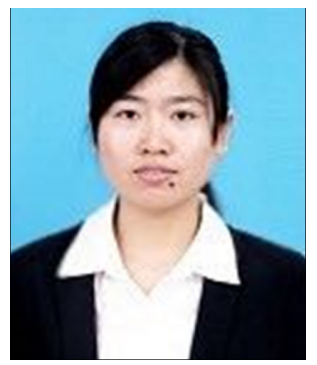

$\boldsymbol{L u} \boldsymbol{Y} \boldsymbol{u}$ is a ph.D. of college of Environmental Science and Engineering at Ocean University of China. Her research interests include groundwater pollution and control, environmental planning and management.

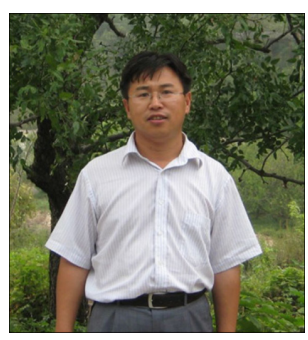

Guanqun Liu is a Professer of Ocean University of China. His research is focused on groundwater resource evaluation and management, water environmental protection and management. He has published nearly 100 research papers in international and Chinese journals. 